\title{
Developing Oral Interaction Skills in Foreign Language Learners through Media Literacy
}

\section{Desarrollo de habilidades de interacción oral en estudiantes de lenguas extranjeras a través de la educación mediática}

Heydi Karen Neiva Montaño'

Citation/ Para citar este Artículo: Neiva-Montaño, H. (2021). Developing Oral Interaction Skills in Foreign Language Learners through Media Literacy. Colomb. Appl. Linguistic. J., 23(1), pp. 3-16.

Received: 02-May.-2019 / Accepted: 05-Apr.-2021

DOI: https://doi.org/10.14483/22487085.13373

\begin{abstract}
Few studies in Colombia have incorporated media literacy in TEFL (Teaching English as a Foreign Language) environments. This paper presents the results of a research conducted in an upper-intermediate course in the Language Institute of the District University (ILUD) in Bogotá. A media literacy model was adapted to create weekly radio workshops in an eight-week pedagogical intervention. During the research study, data were collected from the participants' weekly interactions, discussions, reflections, as well as from semi-structured interviews and field notes taken from my observations as a participant-observer. It was found that EFL learners from a mixed-ability group were engaged in media literacy practices, mainly when they reflected upon news through their realities, beliefs, and attitudes. The results of this study demonstrated that students developed oral interaction skills and acquired diverse strategies that helped them discuss messages from different media outlets, express their personal opinions, and gather additional information to support their findings.
\end{abstract}

Keywords: media literacy, media messages, mixed-ability group, oral interaction skills, TEFL environments

\section{Resumen}

Pocos estudios en Colombia han incorporado la educación mediática en entornos de enseñanza del inglés como lengua extranjera (TEFL). Este artículo presenta una investigación hecha a un curso de inglés intermedio-alto en el Instituto de Lenguas de la Universidad Distrital (ILUD) en Bogotá. Se adaptó un modelo de educación mediática para crear talleres de radio semanales en una intervención pedagógica de ocho semanas. Durante el estudio investigativo, se recogieron datos de las interacciones, discusiones, y reflexiones semanales de los participantes, así como de entrevistas semiestructuradas y notas de campo de mis observaciones como participante-observador. Se encontró que los estudiantes de inglés de un grupo de habilidades mixtas se involucraban en prácticas de educación mediática, principalmente cuando reflexionaban sobre noticias a través de sus realidades, creencias y actitudes. Los resultados de este estudio demostraron que los estudiantes desarrollaron habilidades de interacción oral y adquirieron estrategias que ayudaron a discutir mensajes de diferentes medios de comunicación, expresar sus opiniones y reunir información adicional que sustentara sus reportes.

Palabras clave: educación mediática, mensajes mediáticos, grupos de habilidades mixtas, habilidades de interacción oral, entornos de enseñanza del inglés como lengua extranjera

1 Universidad de Los Andes (Colombia). ORCID (D): https://orcid.org/0000-0002-4547-0693. hk.neiva@uniandes.edu.co 


\section{Introduction}

There are thousands of sources of information that have been used for academic or entertainment purposes (Frechette, 2005), which consumers are not always aware of. This information must be critically analyzed using media literacy. Turner et al. (2018) assure that the best place to start this process is school, by including media literacy in the curricula. It is necessary to bring media literacy principles into the classroom and work collaboratively to find out what is true or not (Turner et al., 2018). Share \& Mamikonyan (2020) report that few teacher education programs prepare preservice teachers in this way, but they recognize that this need is growing.

Studies regarding EFL environments and media literacy are few; Cooper (2002) claims that media literacy offers a more transparent window into American culture. It helps students master English, fortifies students' identities (Kellner, 2011), and gives them a chance to put their ideas into words (Semali, 2005). Kellner (2011) argues that media images help shape our view of the world, and media stories provide resources that constitute our cultural values. For this reason, English teachers should help students decipher the messages they encounter, use, and share (Share \& Mamikonyan, 2020).

Rogoff (2003) claims that Teaching English as a Foreign Language (TEFL) activities should be designed using a more socio-cultural approach, which includes meaningful content based on the learners' interests (as cited in Tuan E Nhu, 2010). The teacher's role must include previous preparation and a clear understanding of the connections within media literacy, culture, and communication (Dvorghets \& Shaturnaya, 2015). Moreover, Couldry (2012) mentions that teachers should take advantage of online connections, they change social spaces, and this could be useful to promote interactions inside and outside the classroom.

While analyzing the students' needs at the language institute, it was found that they did not feel confident with their speaking skills, and they wanted to improve them. They stated that there were few opportunities to practice inside and outside the classroom, which affected their performance when speaking in English. Tuan and Nhu (2010) assert that language learners need to be in situations that contribute to their involvement in communication. Additionally, the District University has its radio station called LaUD 90.4, therefore creating radio workshops could be a powerful tool to develop their socio-cultural and communicative skills. It was an opportunity to let them 'speak', to say what they think and express themselves. Semali (2005) argues that teachers could achieve this by encouraging learners to create their own media messages and give them a chance to put their ideas into words. To develop this research study, the following research questions were set:

- What strategies do students use to promote oral interaction when working on media literacy activities?

- What are the participants' perspectives on the use of these strategies?

Research involving media literacy in language teaching has been increasing in the last few years in Colombia. Pineda and Núñez (2001) assure that incorporating global issues into the classrooms facilitates the transition from dependent to independent learning. Zárate (2016) used media literacy to promote critical thinking in secondary school students. She confirmed that English language learners developed critical analysis when reading TV advertisements. However, language teachers are not always familiar with digital media use, and they do not always incorporate multimodal texts that could open spaces to create messages and enrich the classroom language (Mora et al., 2018). For instance, in the United States, only $2 \%$ of all teacher training programs are devoted to critically evaluating media, culture, and society (Tiede et al., 2015, as cited in Share \& Mamikonyan, 2020). In Colombia, the Ministry of National Education (MEN) established standards for Information and Communication Technologies (ICTs) only in under-graduate programs (Peña, 2008, as cited in Manrique-Grisales et al., 2017). But soon after the COVID-19 pandemic, the Colombian government decided to improve connectivity to public schools' students and reinforce ICT pedagogy to teachers (MEN, 2020). 


\section{Theoretical perspectives}

\section{Media literacy}

Language learners are involved in a meaningful way when they understand how communication works in a foreign language, rather than only performing it. Once practical communication in L2 is understood, classroom tasks become more valuable for students (McDonough \& Shaw, 1995). Hobbs (1998) assures that media literacy is still an umbrella concept, with a wide spectrum of different educational philosophies, theories, frameworks, practices, settings, methods, goals, and outcomes" (as cited in Potter E Byrne, 2009, p. 345).

The concept of media literacy is defined principally from the voices of many educators who advocate for the learners' ability to express their own opinions through diverse media, as well as the power to 'see through' what the mass media currently offers (Kellner, 2011; Schwarz, 2005). Kellner (2011) also argues that "the media should be a source of cultural pedagogy because it teaches us how to be citizens in this society; thus, we could learn how to read, criticize, and resist socio-cultural manipulation" (p. 7). Through media literacy education, the way people think about the world is revealed, as well as the way they act within it and upon it. Cortés (2000) states that education about "diversity will always be self-limiting in its effectiveness if educators do not seriously engage the reality of students learning about 'otherness' through the media" (as cited in Semali, 2005, p. 39). When Cortés uses the term 'engage', it has a broader meaning than complaining about diversity in all its forms; it does little to recognize the mass media's multicultural teaching power.

On the other hand, some scholars also believe that media messages are being negatively processed. The media promotes attitudes that affect health, safety, and voting, as well as promoting consumerism (McBrien, 2005). Thus, the role of the teacher is essential to show learners media literacy skills. The main objective when teaching through media is not merely to achieve critical awareness and understanding, but also vital autonomy (Mastermann, 1985, as cited in Schwarz, 2005, p. $11)$ to familiarize their minds with media messages.
When students analyze different kinds of media texts, such as film, video, the Internet, and so on, they must acquire specific abilities, which will progressively build their critical reading. Martins (2008) refers to media literacy as one of the digital literacies. He states that the key to becoming digitally literate is through critical thinking (as cited in Alvermann et al., 2012). For this reason, it is necessary to combine media studies with information and communication technologies (ICTs), which refer to digital, multimodal, and globally networked information (Share \& Mamikonyan, 2020). Luke (2001) assures that many students are already literate in the cyberspace; they can search Internet and produce texts. However, students are not yet skilled in applying critical analysis (as cited in Frechette, 2005). We must recognize students' affinity with multimodal texts because there is evidence that critical digital literacy (CML) instruction is keeping pace (Alvermann et al., 2012).

There is a thriving understanding of the importance of ICTs and media literacy in the classroom environment because they promote students' autonomy and self-consciousness in their learning process (Bohorquez \& Hine, 2009; Esteban, 2009). Teachers could guide students in the process of developing critical thinking skills concerning the texts they see and create online (Alvermann et al., 2012). However, teachers need to be prepared (Clavijo \& Espitia, 2011) and understand what makes electronic communication unique (Share E Mamikonyan, 2020). They could create opportunities for students to invest in their learning process, as well as organizing activities with meaningful content according to their English level and needs, namely the development of projects where students can design podcasts (Chan et al., 2011) and radio programs (Bohorquez \& Hire, 2009) or participate in virtual classrooms.

\section{Oral interaction in EFL classrooms}

The development of oral interaction in L2 environments has been a matter of study in recent years. Thus, many scholars agree that this skill goes along with the development of social relationships and creative learning environments. The inclusion of local contexts and learners' backgrounds is part 
of the theories of several scholars whose ideas have progressively shaped this study. Literature confirms that interaction is promoted when there is a collaborative environment in the classroom, that is, where the students work in pairs or groups. They can express their thoughts and ideas, thus supporting each other in the process of learning a language. River (1987) mentions that students use all language resources during classroom interactions, including everything they have learned or casually absorbed (as cited in Tuan \& Nhu, 2010).

Students improved their English skills from listening and talking to others. Thus, expressing themselves orally in English has great importance in our society today (Tornqvist, 2008). Tornqvist argues that factors like pupils' self-esteem, a safe classroom climate, enthusiastic and encouraging teachers, meaningful assignments, small groups, and motivation among the pupils contribute to orally active pupils in the English foreign language classroom. On the other hand, Gan (2012) states that a low input in spoken communication in ESL students contributes to socio-cultural, institutional, and interpersonal problems.

As a result of the mentioned principles, the Interactional Communicative Theory (ICT) explains how L2 and society reshape oral interaction analysis. Additionally, ICT explores learners' abilities to start, continue, and finish conversations in acceptable ways and manage the switch between options. One needs to know the conventions of turn-taking, when to begin speaking, and when to stop (Fulcher, 2003). Moreover, with the recent growth in fields such as discourse and conversational analysis, we now have a much clearer picture of how conversations are structured.

In Colombia, Castrillón (2012) worked to identify the factors that influence the practice of English oral communication skills among students. The author noticed that most participants perceived an improvement in the different factors related to developing their oral skills. The researcher concluded that practicing in small groups or with peers was the only way to foster interaction, and it was more effective than learner-teacher interaction or practicing with the entire class. Promoting discussions in groups or pairs nurtures collaboration, and learners can clarify ideas in a free setting without the teacher's inspection (Gillies, 2006, as cited in Tuan \& Nhu, 2010).

One of the models used to identify student interactions in this study was the FLINT model. Gertrude Moskowitz proposed it in 1976, and it was later adapted by Brown in 2001. This model is essential to identifying the active role of teachers when promoting classroom interaction. It bases its analysis on a nine-category framework, in which seven are focused on the interactions of teachers and two on the interactions of students. This model was readapted for this study, considering the categories of student interactions and with the inclusion of gambits/prompts (Keller \& Warner, 1988), as well as oral recasts/corrective feedback (McDonough, 2000). (see Figure 1)

Keller $\&$ Warner (1988) mention that a conversation sounds more natural when using gambits. A gambit is a word or phrase that helps to express what we are trying to say. Some examples of these expressions are: 'really!', 'I have heard that', 'by the way', etc. In one sense, a gambit has very little meaning - it does not express an opinion; it may only introduce it -whereas corrective feedback or oral recasts can help construct meaning-making connections to acquire a second language. However, learners do not usually notice or misinterpret the intention of the recast. (McDonough, 2000 as cited in Bigelow et al. 2005). This model's adaptation was found to be very convenient for this study, and it was taken into account when analyzing oral interactions.

\section{Methodology}

\section{Pedagogical intervention}

For this pedagogical intervention, the media literacy model called The Empowerment Spiral was adapted, and a schedule was proposed. According to Thoman and Jolls (2010) this model has proven to be an excellent process for uncorking a spiral of inquiry that promotes comprehension, greater critical thinking, and the ability to make informed judgments." (p.198) (see Figure 2). 


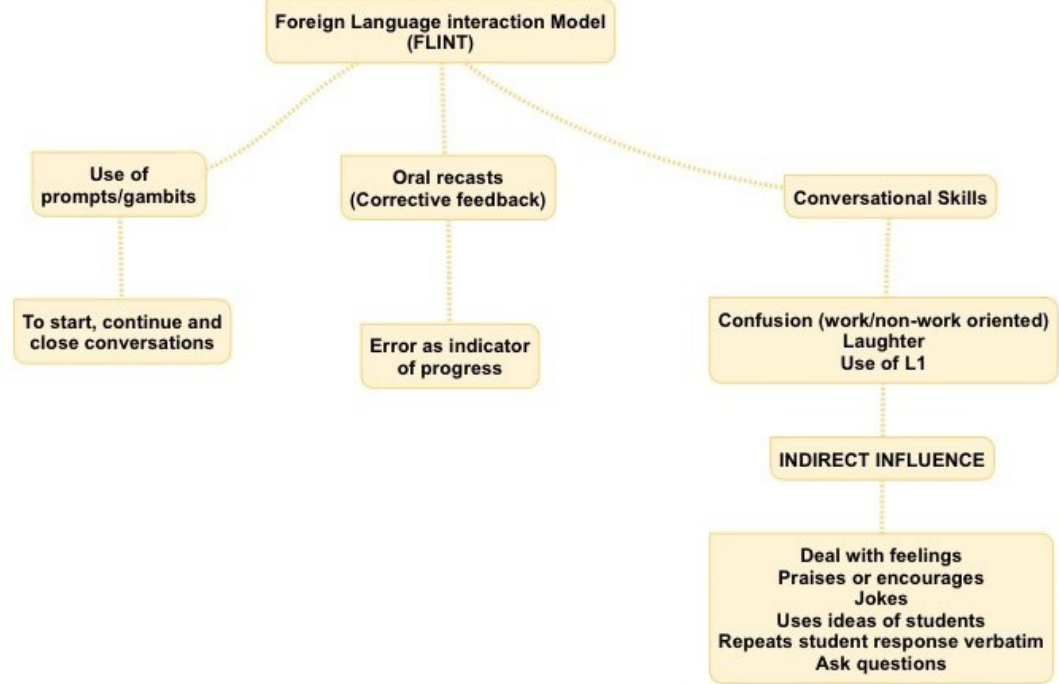

Figure 1. FLINT Model adapted from Brown (2001)

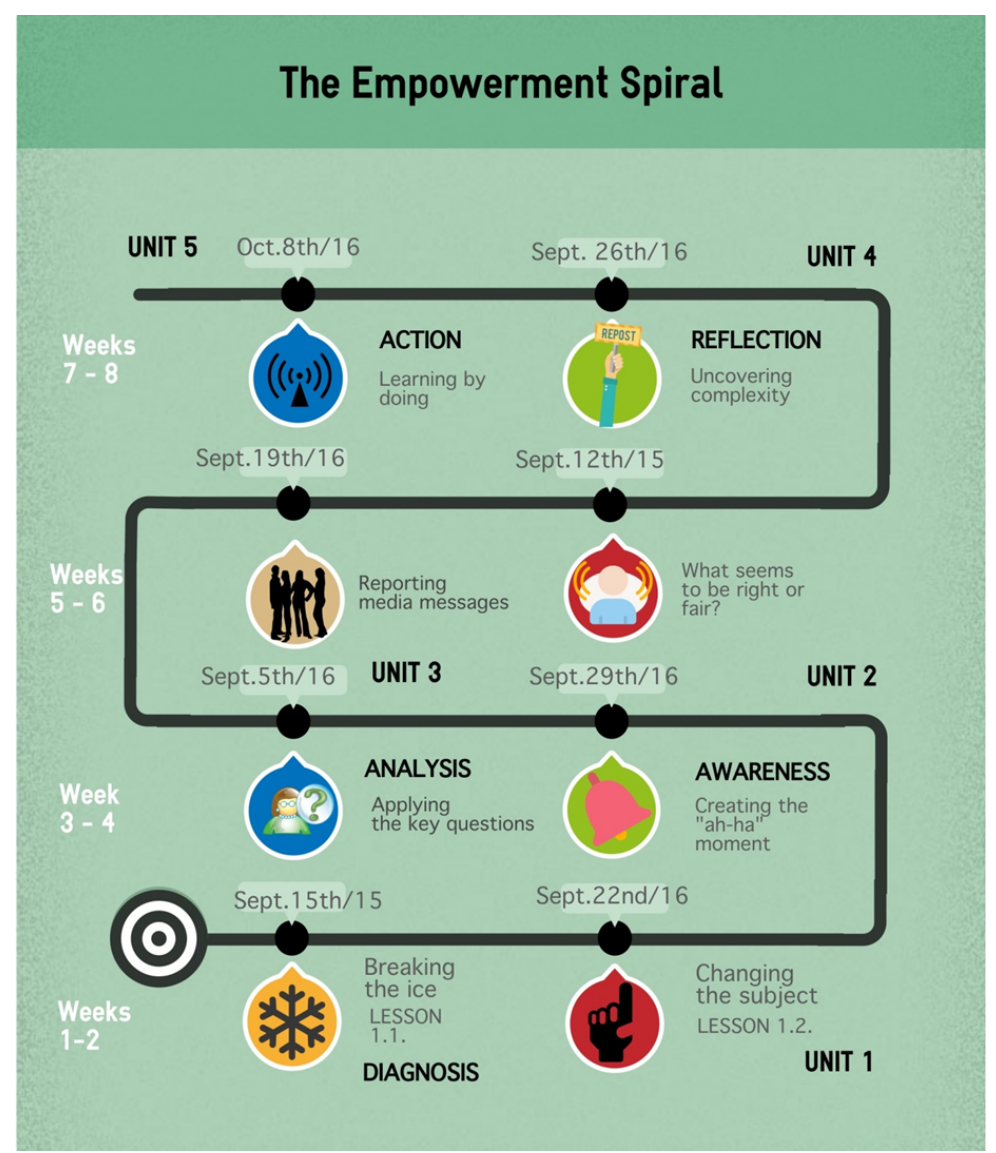

Figure 2. Pedagogical intervention scheme based on The Empowerment Spiral, taken and adapted from Thoman and Jolls (2005) 
As shown in the Figure above, the five stages of this pedagogical intervention took place over eight weeks. During this time, the participants worked on pedagogical lessons (called radio workshops) that were part of the five didactic units designed.

Stage 1: Diagnosis - identifying oral interaction skills. In the first stage, the students were introduced to the radio program Breaking the Ice from the BBC/learning English website and were provided with the corresponding audio-script. After listening, the students formed small groups and recorded their interactions using a first set of gambits with their classmates.

The topic of the second day of class was how to start a conversation with someone you meet for the first time. On that day, the strategy was to develop discussions using prompts and to interrupt one another. The students completed the exercise twice, once with the topics from the workshop, and they chose the topic of discussion for the second run.

Stage 2: Awareness - creating the "ah-ha" moment. This stage is the first step to develop the students' inquiry process and was based on the interviews completed after the students listened to the radio program. Through a role-play activity, the participants were journalists and took turns to interview one another to discover which famous person the interviewee would like to meet. Previously, the participants researched about a celebrity they admired. In class, the students worked in pairs to develop the conversation by listening and asking questions.

Every time they finished asking, they rotated partners and exchanged roles from journalist to interviewee. During the interviews, the students asked as many questions as possible because the idea was not to tell the person's name. Therefore, the journalist had to guess the name at the end of the interview.

Stage 3: Analysis - uncovering complexity. In this stage, the students organized and planned the radio programs. Firstly, the participants researched the news that they wanted to share with the class.
Secondly, they worked in groups to analyze how an issue came to be. Thoman and Jolls (2010) proposed The Five Key Questions technique to better understand the complexity of a particular issue.

Like a journalist, the students asked how, what, why, when, and where questions. This technique enhances creative experiences and makes them understand what happens between a media producer and the audience. It is known that "why' questions often lead to speculation, personal interpretation, and circular debate, rather than the critical process of inquiry, exploration, and discovery" (Thoman $\mathcal{E}$ Jolls, 2010, p.198).

Stage 4: Reflection - what seems to be right or fair? In this stage, the students went beyond the basic questions and asked, 'so what?' or 'what should they do?' (Thoman E Jolls, 2010). Based on their chosen topics, students designed a survey and applied it with people in their social circle. Afterwards, the students reported the questions that they asked within the group. The reflections were diverse, as well as the topics chosen: sexual diversity, political conflicts, social justice, transportation, medical advances, environmental concerns, among others. Certain issues were debated more than others; sexual orientations and political conflicts were more popular than news about science, technology, or entertainment.

Stage 5: Action - learning by doing. The last stage of this pedagogical intervention was creating two radio programs according to the indepth analysis and reflections carried out in the two previous stages. The participants had the opportunity to formulate constructive action ideas. Thoman and Jolls (2010) claim that, in media literacy contexts, action is equated with "activism" and "advocacy" (p.199). In this stage, the participants designed the script, gave their partners feedback, and contributed to creating the radio program.

The result reflects all their hard work and involvement in the project, which in this case, was the radio program. Thoman and Jolls (2010) state that some projects may involve a public showing. However, the most extended actions are often 
simple activities that symbolize increased internal awareness. The students gathered in groups depending on their areas of interest: technology o socio-cultural news. They worked autonomously to create a script and used Google Drive to share the document and added their unique ideas. On the last day of class, the students gathered their thoughts and recorded the radio program. In the end, two radio programs were created: All you need to know and Secrets of life. The programs were broadcasted on the university radio station, and they can be listened to on: http://laud.udistrital.edu.co/pro/ taking-wing.

\section{The study}

This research is framed in a qualitative approach, which is used to gather in-depth insights into a problem or situation at a much more focalized point. The stated problem has to do with the lack of interaction of EFL adult learners and its effect on L2 oral interactions. Merriam (2009) claims that "a qualitative study is sensitive to underlying meaning when gathering and interpreting data" (p.2), and it is more concerned with understanding an individual's perceptions of the world.

A qualitative descriptive case study is the best option for answering the first research question (what strategies do students use to promote oral interaction when working on media literacy activities?) It offers insights that can be seen as tentative hypotheses, which could help structure future research. Case studies play an essential role in advancing the knowledge base of a specific field, and they may be selected as examples of a process, an issue, or a specific concern (Merriam, 1998). In this study, the participants were foreign language learners who participated in EFL radio workshops as an innovative project that helps develop oral interaction skills. To complete the data analysis, the grounded theory framework was used. This inductive method consists of systematic, flexible guidelines for collecting and analyzing information to construct theories 'grounded' in the specific data (Charmaz, 2014). During this process, the way the participants make sense of their experiences was made evident, as well as the logical sense of their meanings and actions.

\section{Participants and context}

The participants in this study were diverse, given their different needs and backgrounds. Therefore, they are called a mixed ability group. Some of them were university students from the private and state sector. There were also many professionals from different fields, such as engineers, lawyers, and state/private school teachers, as well as secondary school students who have finished their studies and decided to learn a foreign language.

The social stratum was quite diverse as well; most students were between strata 1 to 4 , with three being the most common. Classrooms typically have between 15 and 25 students, depending on the level. However, most students take basic language level classes. For this study, the sampling population was taken from the upper-intermediate groups; 15 students aged 16 to 39. The number of hours in each level was 48 , distributed over eight weeks, with two hours per session, three days a week, or Saturdays from 7 am to $12 \mathrm{pm}$.

\section{Data collection}

At the beginning of the intervention, the semistructured interviews were recorded to gather the insights of their English learning experiences in order to carry out the diagnostic stage of this research study. Burns (1999) argues that semistructured interviews enable the interviewee's and the interviewer's perspectives to form the research agenda and encourage a better-balanced research relationship. Then, the radio workshops' recordings were collected; the discussions in the media messages were very important while analyzing the data. Field notes were an essential part of the process, and I recorded my observations during the intervention. These notes helped gather the information that I could not hear on the audios but registered as a participant-observer. During the interactions, the students' attitude, sense of commitment, and collaborative work were not easy to perceive in audio.

Consequently, these recordings were transcribed to organize and create a systematic and consistent 
codifying process through ATLAS.ti. By finding commonalities in the strategies used to interact, the categories and subcategories that answered the research questions were named. This article describes the first of these categories because it contains the strategies used during the pedagogical intervention.

\section{Findings}

During the data analysis, two categories were identified: Building up media messages reflections in L2 to develop group discussions and Valuing the strategies to promote interaction. In this article, the first category and its four corresponding subcategories are described in detail. (Figure 3 ).

\section{Building up media messages reflections in L2 a mixed-ability group}

The social backgrounds, education, and professional interests of the participants resulted in the development of different sets of cognitive skills, with which they analyzed and reflected upon their choices. However, it was made evident that there were different opinions and attitudes towards the presented topics. The participants probably chose specific media messages because they felt they were the most suitable according to their beliefs and demonstrated their positions. Four subcategories aid in analyzing different types of strategies commonly used during the pedagogical intervention: Using prompts to start, continue and close conversations; Error as an indicator of progress; Encouraging peers to develop criticality, and Sense of humor to release tension; and develop L2 interactions.

Subcategory 1: Using prompts to start, continue, and close conversations. The first lessons of the pedagogical intervention were structured so that participants were initially able to use prompts. This strategy was progressively used during the pedagogical intervention, and the transcriptions demonstrated how the students constructed their conversations through these structures and applied these strategies in the radio workshops. The following excerpt shows how the students used some of the prompts learned during the creation of the radio program. They created a program called Secrets of Life, and it was about scientific and technological news.

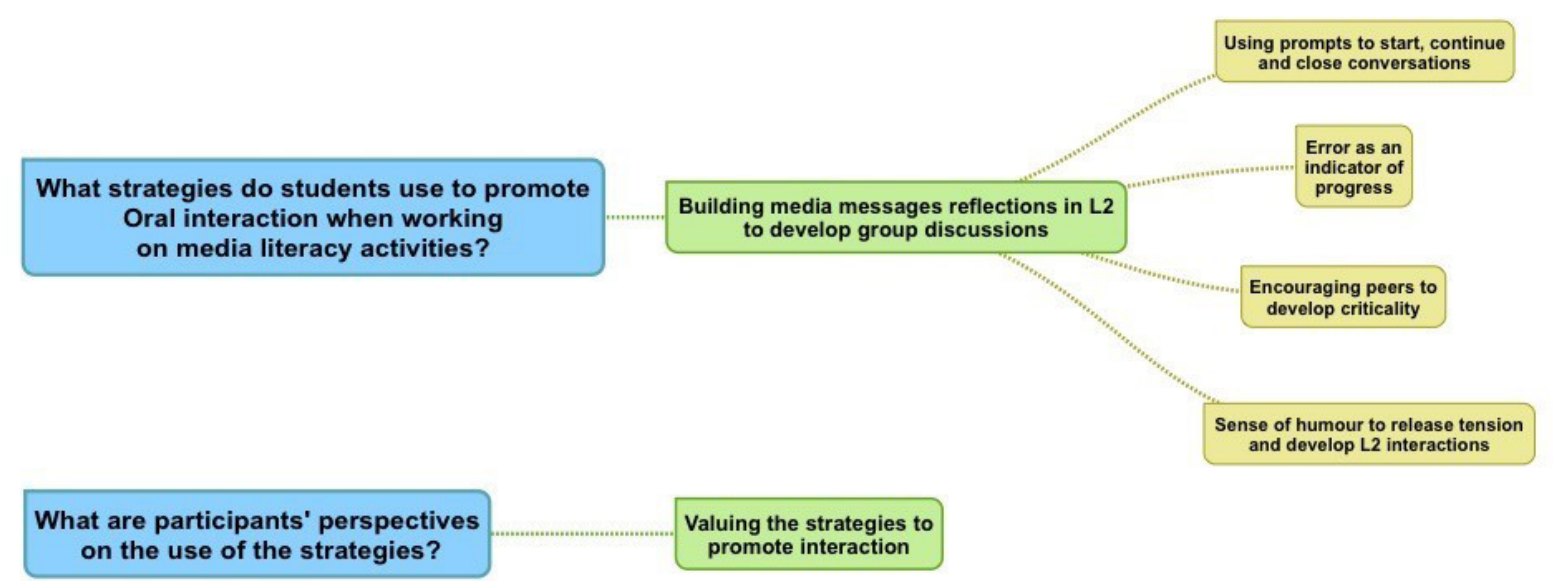

Figure 3: Research questions, categories, and subcategories 
Unit 5 - Lesson 5,1 (03-10-15/4'43II)

1.Student A: Hello, do you know that $x x x x x$ against HIV could be administered in 2016 ?

2.Student B: Really? It can help people sick people.

3.Student C: Oh, I didn't know, tell us more about that.

4.A: xxxx -streaming- and reduce cost, according to an interview, everybody think that

5. education is the most important to fight against HIV, because is very important to prevent it.

6.Student D: So interesting Sandra, talking about medicine discoveries, I read that biomedical

7.engineering has tried to create artificial organs with $\mathrm{xxxx}$ or matters [materials]

8.C: Really! how does it work?

9.D: It's incredible but scientist said that the work was so hard because they must put some so cell in a 10.matrix and they put organ model and modify the DNA. It is amazing!

In this excerpt, it is interesting to see how the participants activated the conversation with prompts that they learned at the beginning of the pedagogical intervention and were acquired with the radio workshops' evolution. It was evident that prompts help L2 learners develop conversations, and it is a strategy that needs to be nurtured during the language learning process, mainly when reflecting upon controversial media messages. As it was identified from the beginning of the study, the participants started using the prompts given in the first pedagogical lessons to interrupt conversations or show interest. However, they progressively adapted the prompts that, in some ways, helped them build their repertoire, as well as to be able to support their peers in the development of their ideas when interacting.

Subcategory 2: Error as an indicator of progress. The mistakes that the students made were part of their conversations and helped them develop their ideas and reflections. One of the most recurrent commonalities was the use of oral recasts. The following excerpt is from the second stage of this pedagogical intervention (called the awareness stage). The idea was to introduce the learners to radio programs that showed examples of interviews. For example, a section of a podcast from the BBC's English learning website called I'd like to meet. This activity aimed to learn how to interview one another. The participants shared the most relevant details about a person they would like to meet. Their partner asked them questions to gather more information. The following excerpt shows how participants corrected themselves when interacting:

(1.2) Unit 1-Lesson 1.3. (29-08-15)

1. A. fine e: today I am going to talk about my favourite women e: Colombian women

2. B: oh really!?

3. A: really, e:rm: she is famous e: in our country and I want to tell you how I see her, like a model of 4..women

5. B: ok I see

6. A: ok e::rm before I think that I have I had the opportunity to meet her=

7. B: you meet her> met met her [laughs]

8. A: yes, really e:: she has one daughter and one son

9. B: and did your meet with her sons?

10.A: no, e: the son, the son have, the son is like years old and her daughter e:r the same I

11.think

12.B: ok

13.A: she loves sport, healthy life and she is ambassador of different branch

14.B: really!

15.A: really, like e: all we know like Adidas, mango and the north fitness gym

16.B: right

17.A: e:rm like e:r I told you before, I had the opportunity to meet her and she

18.B: when, when did you met with her

19.A: the last month,

20.B: ah is very recently

21.A: yes, she I met her in the gym,

22.A: how, Occasionally?

23.A: no, I win I won a class in the north fitness gym and then she was there

24.B: ok

25.A: e: she is a people person, is funny, intelligent, beautiful, humble and I admire her 26. because she $r$ ise her family e: and her family is so beautiful

27.B: ok 
28.A: e: she likes talk about my favourite topics, like food, fitness, sport, wellness, eee

29.government, globalization, civi...e: civil topics, movies, series,

30.B: so can you talk with her?

31.A: yes, a long time

32.B: ah ok!

In this conversation, participants corrected themselves when interacting. However, this did not stop them from constructing their ideas (lines 6, 7, 10, and 23). It was essential to see how Student A went along and described why he admires the person he chose, explaining that this person has many positive aspects; overall, this person has raised her family. It could be observed that the participants chose their characters because they are models to follow. Their admiration goes beyond physical appearance or money; it has to do with their beliefs and other desires. This interaction shows how participants used oral recasts to develop their conversation skills and were more interested in finding out who they were, rather than stopping themselves from making mistakes.

Subcategory 3: Encouraging peers to develop criticality. From the first lesson, the support provided among participants was observed, either through comments or questions. The following excerpt shows the progress of the inquiry process throughout the radio workshops. First, the students asked questions to gather more information about the news. Secondly, they developed a survey, applied it in their social circles, and later reported their findings to their group. The following excerpt is from the scientific and technological group:

(1.5) Lesson 2.2 (05-09-15)

1. A: =biomatters, biomatters $=$, $\mathrm{e}$ : in this moment, in a lab is crea...creating a new organs ... e: any 2.question?

3. B: [laughs] e: e: you were talking about reactions? Xxx for example the reaction.human heart

4.has, ... I mean ... someone can have a reaction

if has another heart $x x x x$

5.A: yes, but is only for the people that need that need the: cirugía=

6.C: =surgery=
7.A: ciu:rgery and that=

8.D: why do you like that kind of news?

9.A: ha:

10.B: yes!

11.A: a: because is about my career a:nd and I think that that news was fantastic because they change the 12:world and and will xxx the new androids in humans.

In this interaction, the participants talked about artificial organs, a topic originally researched by Student A (17 years old), a university student. Even though it was a complex topic, his peers continuously developed their inquiry process (lines 3 and 8). This oral interaction shows constant collaborative work that enhances speaking skills, as well as the importance of constructing a critical framework for understanding media messages.

Subcategory 4: Sense of humor to release tension and develop L2 interactions. This subcategory arose from the strategies that participants frequently used to create radio workshops. It was clear that, in order to avoid uncomfortable, silence or relieve stress, students often choose to use humor in their conversations to complete the task. Commonalities in the codes, such as jokes and laughter, as well as their frequency in their interactions, shaped this subcategory. The following excerpt shows the use of the participants' sense of humor to build their conversations and construct social relationships:

(1.8) Unit 3 - Lesson 3.1 - (05-09-15)

1. A: what hour the eclipse start?

2. B: a: it's going to start at four, hum: twenty to five,

$3 \mathrm{C}:$ what do you think is the reason for this?

4. B: e: ... e: I don "t know, how do you say that...but is because of the ro:.... Rota:.... the:... movement of the earth yeah? I think so [laughs]

6. A: do you like to see this phenom [phenomenon]?

7. B: yeah, yeah, but this is not going to happen

in Colombia but I like that kind of events.

8. A: $x x x$ so when you wake up but you...

9. B: yeah ..

10. A: we wake up at four [laughs] 
11. B: with my family when we were younger or children with my brother we liked seeing the eclipse and 12: that phenomenon happens e: once in a long time yes for that reason I decided to choose that kind of 13. information because is very strange that happens that event yeah?

In this excerpt, Student B reported news about an eclipse, and her peers asked her why she did not see it. Even though she said that it could not be seen in Colombia, her peers asked her if she would wake up at 4 am to see it. Thus, she backed this up by referring that the event was linked with her life experiences, and she used to watch it with her family. This proves that, when the participants are engaged with the activity, they show that they listen to each other, even though they do not always understand what is said. Thus, they start interacting by using personal questions from the information received and expressing their emotions. I noticed that the participants used this strategy when they did not know what to say or did not understand their peers. It was also used when they made mistakes; if they felt comfortable, they teased each other, mostly in small groups.

\section{Conclusions}

The analysis and interpretation of strategies used throughout this category and their subcategories lead to the conclusion that L2 students developed oral interaction skills by using different strategies when reporting media messages. The analysis showed that the students used prompts to fit their personalities, especially those who showed interest in interacting with their peers. When participants built social relationships, it was much easier to utilize prompts that motivated their peers to develop their communication skills.

The participants did not stop reflecting on media messages when they made mistakes; on the contrary, they kept developing their ideas, primarily when they were engaged in expressing their opinions, past experiences, and future desires about topics that interested them. There were different areas of interest reported in the radio programs, and it was noticeable that the participants asked more questions when the message was not clear, or they disagree. Oreskes and Conway (2010) argue that students need to be skeptical of everything, even science, which is often considered to be objective (as cited in Funk et al.,2019). The first step to developing critical thinking is analyzing and creating meaning from any content that is taught.

Peer corrective feedback/oral recast occurred when the participants had more opportunities to interact and build confidence, which allowed them to feel more comfortable with giving and receiving feedback. The participants were more conscious of their learning process. The most common type of corrective feedback was the short recast, which is to repeat the utterance corrected by their peers or themselves. McDonough and Shaw (1995) state that corrective feedback allows learners to focus their attention on non-target components of their speech at moments when they are focused on meaning (as cited in Bigelow et al., 2005).

When the participants engaged in the inquiry process, they listened carefully to their peers to understand the media messages and reflect upon them. Using L2 to interact forced the student to understand the messages and continue the debate, which sometimes does not occur in their mother tongue. The participants were able to collect the information and reflect upon the answers received. For example, some of them argued that it was not easy to be open-minded about sexual orientations, especially in schools. These reflections show the power of the established system of values, which encompasses family, school, and society. It has played a predominant role in promoting values (Funk et al., 2019). The way in which the media different social agencies can transmit this information, predisposes people to accept some matters and not others (Funk et al., 2019). These different values were reflected in the class and showed the invisible intellectual and unconscious boundaries of social choice.

Some students chose to use humor to further the conversation and complete the task. When the students did not understand the message or found 
themselves in an awkward situation due to language barriers, they often made fun of themselves and their peers to relieve stress. The students were able to play jokes around and laugh, even when the messages were not completely understood. The students also learned how to tease each other in L2, which occurred when they had more opportunities to interact and build connections with their peers. Interactional theories (ICT) propose that students use their backgrounds and personalities to add to the learning experience. Bringing media messages to the classroom activated the students' critical thinking and transformed the learning language into a more meaningful experience (McDonough $\mathcal{E}$ Shaw, 1995).

At the end of the last radio workshop, there were some difficulties that the participants encountered when working in small groups. Some participants did not contribute significantly to the elaboration of script, and this behavior affected the others. It is advisable to spend some time in class to elaborate the script rather than leave it as homework. In this particular case, the radio workshops were additional activities in the course program. The time given was not enough because there were some other projects and activities to cover. It was not easy to connect the radio workshops with the curriculum and including media literacy practices in language programs would have a lot of benefits. More importantly, preservice and in-service teachers get more involved in developing materials that enhance media literacy practices in local contexts.

Finally, the media literacy model used during this pedagogical intervention progressively facilitated oral interactions. Its short-term learning steps helped decipher complex topic concepts discussed during the radio workshops. Thoman and Jolls (2010) explain that The Empowerment Spiral's actions stimulate different aspects of the brain and enhance the ability to create new knowledge from past experiences. Media literacy offers an incredible spectrum of possibilities that language teachers could keep exploring and adapting to further enrich language teaching experiences. Moreover, it would be pertinent to explore more in-depth Critical Media Literacy (CML) and digital literacy in EFL classrooms. Funk et al.,
(2019) assert that "there is much pedagogical potential for students when they are involved in creating media that can push back and challenge dominant myths and stereotypes" (p.13).

\section{References}

Alvermann, D. E., Hutchins, R. J., E McDevitt, R. (2012). Adolescents' Engagement with Web 2.0 and Social Media: Research, Theory, and Practice. Research in the Schools, 19(1), 33-44.

Bigelow, M., Delmas, R., Hansen, K., \& Tarone E. (2005). Literacy and the processing of oral recasts in SLA. TESOL Quarterly, 40(4), 665-689. https:// doi.org/10.2307/40264303

Bohorquez, C. R. \& Hine, N. (2009). Media as a medium in Colombian education: how media and ICT are changing communication and the curriculum in the school. Colombian Applied Linguistics Journal, $11,15-123$.

Burns, A. (1999). Observational techniques for collecting action research data and non-observational techniques for data collection. Collaborative Action Research for English Language Teachers (pp. 79-151). Cambridge University Press.

Castrillón, V. (2012). Students' perceptions about the development of their oral skills in English as a foreign language teacher training Program (Publication No. 372452C355) [Thesis, Universidad Tecnológica de Pereira. Colombia]. http:// repositorio.utp.edu.co/dspace/handle/11059/1911

Chan, S., Chi, S., Chin, K., E Lin, C. (2011). Students' Perceptions of and Attitudes towards PodcastBased Learning - A Comparison of Two Language Podcast Projects. Electronic Journal of Foreign Language Teaching, 8, 312-355.

Charmaz, K. (2014). Constructing grounded theory: a practical analysis. SAGE.

Clavijo, A. E Espitia, M. I. (2011). Virtual Forums: A Pedagogical tool for collaboration and learning in teacher education. Colombian Applied Linguistics Journal, 13, 29-42. https://doi. org/10.14483/22487085.3763

Couldry, N. (2012). Media, society, world. Social theory and digital media practice. Polity Press.

Dvorghets, O. S. E Shaturnaya, Y. L. (2015). Developing students' media literacy in the English language teaching context. Procedia, 200, 192-198. https:// doi.org/10.1016/j.sbspro.2015.08.051 
Esteban, M. (2009). Looking for a path to involve media literacy in an EFL setting. Enletawa Journal, 2, 6574.

Frechette, J. L. (2005). Critical thinking for the cyberage. In Schwarz, G. E Brown, P. U. (Eds.), Media literacy: Transforming curriculum and teaching (pp. 100118). Blackwell. https://doi.org/10.1111/j.17447984.2005.00007.x

Fulcher, G. (2003). Applied linguistics and language study: testing second language speaking. In Candlin, C.N. (Ed.), Testing Second Language Speaking. Pearson Longman.

Funk, S., Kellner, D., E Share J. (2019). Critical media literacy as transformative pedagogy. In Yildiz, $M$. $\mathcal{E}$ Keengwee, J. (Eds.), Handbook of research on media literacy in the digital age (pp. 318-348). IGI Global Publisher of Timely Knowledge. https://doi. org/10.4018/978-1-5225-8359-2.ch019

Gan, Z. (2012). Understanding L2 speaking problems: implications for ESL curriculum development in a teacher training institution in Hong Kong. Australian Journal of Teacher Education, 37(1), 43-59. https://doi.org/10.14221/ ajte.2012v37n1.4

Hobbs, R. (2005). Media literacy and the k-12 content areas. In Schwarz, G. \& Brown, P.U. (Eds.), Media literacy: Transforming curriculum and teaching (pp. 74-99). Blackwell. https://doi.org/10.1111/ j.1744-7984.2005.00006.x

Keller, E. E Warner S. (1983). Conversation gambits, real English conversation practices. Language Teaching Publications.

Kellner, D. (2011). Cultural Studies, Multiculturalism, and Media Culture. In Dines G. \& Humez, J. M. (Eds.), Gender, race, and class in media. A critical reader. (pp. 7-17). SAGE.

Manrique-Grisales, J., Sandoval, R. Y., \& Fernandez A. A.(2017). Media competence in Colombia: reference frameworks for a diagnosis. Nexus Comunicación, 21, 6-33.

MEN (Ministry of Education of Colombia). (2020, March 31). Gobierno fortalecerá las competencias digitales en los colegios públicos con la política pública de Tecnologías para Aprender. https://www. mineducacion.gov.co/1759/w3-article-395101. html? noredirect $=1$

McDonough, J. \& Shaw C. (1995). Material and methods in ELT: A teacher's guide. Blackwell.

McBrien, J. L. (2005). Uninformed in the information age: why media necessitate critical thinking education. In Schwarz, G. \& Brown, P. U. (Eds.), Media literacy: Transforming curriculum and teaching (pp. 18-
34). Blackwell. https://doi.org/10.1111/j.17447984.2005.00003.x

Merriam, S. (1998). Qualitative research and case study: Applications in education. Jossey-Bass Publishers.

Merriam, S. (2009). Qualitative research: A guide to design and implementation. Jossey- Bass Publishers.

Mora, R. A., Pulgarín, C., Ramírez, N., \& Mejía-Vélez, M. C. (2018). English literacies in Medellín: the city as literacy. In Nichols, S. \& Dobson, S. (Eds.), Learning cities, cultural studies and transdisciplinary in education 8 (pp. 37-60). Springer Nature Singapore Pte Ltd. https://doi.org/10.1007/978-981-10-810024

Pineda, B. C. E Núñez, P. A. (2001). Getting in touch with reality: an English curriculum to boost students' critical thinking skills and interest in global issues. HOW Journal, 9(1), 34-39.

Potter, J. W. \& Byrne, S. (2009). Media literacy. In Nabi, R. \& Oliver, M. B. (Eds.), Media processes and effects (pp. 345-357). SAGE. https://doi. org/10.4135/9781412964005.n62

Semali, L. (2005). Why media literacy matters in American schools. In Schwarz, G. E Brown, P. U. (Eds.), Media literacy: Transforming curriculum and teaching (pp. 35-54). Blackwell. https://doi. org/10.1111/j.1744-7984.2005.00004.x

Schwarz, G. (2005). Overview: what is media literacy, who cares, and why? In Schwarz, G. E Brown, P. U. (Eds.), Media literacy: Transforming curriculum and teaching (pp. 5-17). Blackwell. https://doi. org/10.1111/j.1744-7984.2005.00002.x

Share, J. E Mamikonyan, T. (2020). Preparing English Teachers with Critical Media Literacy for the Digital Age. CITE Journal, 20(1), 37-54.

Törnqvist, A. (2008). Oral communication in the English language classroom: A study of the attitudes of some English teachers and 9th-grade pupils in Sweden towards oral communication in the English classroom. (Publication No. 277063518) [Master's thesis, School of Human Sciences, Sweden]. ResearchGate Dissertation Publishing.

Thoman E. E Jolls, T. (2005). Media literacy education: lessons from the center for media literacy. In Schwarz, G. E Brown, P.U. (Eds.), Media literacy: Transforming curriculum and teaching (pp. 180205). Blackwell. https://doi.org/10.1111/j.17447984.2005.00011.x

Tuan, T. L. E Nhu, K. N. (2010). Theoretical review on oral interaction in EFL classrooms. Studies in Literature and Language, 1(4), 29-48. 
Turner, K. H., Jolls, T., Hagerman, M. S., O’Byrne, W., Hicks, T., Eisenstock, B., \& Pytash, K. E. (2018). Developing digital and media literacies in children and adolescents. Pediatrics, 140 (2), 122- 126. https://doi.org/10.1542/peds.2016-1758P
Zarate, Y. (2016). Media literacy to promote critical thinking in the EFL classroom (Publication No. 11349/3108). [Master's thesis, Universidad Distrital Francisco José de Caldas, Bogotá]. https://repository. udistrital.edu.co/bitstream/handle/11349/3108/ Z\%C3\%A1rateLe\%C3\%B3nYolanda2016. pdf? sequence $=1$ EisAllowed $=\mathrm{y}$

\section{(ब) $\Theta \Theta$

